\title{
Village Empowerment: Service-Learning with Continuity
}

\author{
John Duffy \\ Energy Engineering Program \\ University of Massachusetts Lowell \\ John_Duffy@uml.edu
}

\begin{abstract}
Since 1998, as part of the Village Empowerment Program, a total of 119 students/volunteers from University of Massachusetts Lowell (UML) and several other universities in engineering and other fields have traveled twice a year to the same network of villages in Peru. Students in service-learning projects in more than 25 different courses have designed and helped install over 80 systems, most running on renewable energy, in 44 villages and towns in the Andes Mountains of Peru for medical clinics, schools, and town halls. The villages in general have no grid electricity, one pay telephone (or none) per village, no space heating, houses made of adobe, and elevations up to $3600 \mathrm{~m}(11,500 \mathrm{ft}$.). The indigenous Quechua, or Inca, people in the villages survive on subsistence agriculture. The systems power transceiver radios, lights, computers, vaccine refrigerators, and other medical equipment in clinics as well as laptop computers and lights in schools, mostly utilizing solar energy. Water supply and purification systems for whole towns have been added as well as micro hydro and biogas. To help make all these systems sustainable, we return every six months to the same two networks of villages. We are also helping to start microenterprises of aquaculture, of manufacturing and renting solar lanterns and LED headlamps, of biodigesters, and of developing and manufacturing solar water purification bottles coated with a photo catalyst with a dye indicator. The program has transformed the lives not only of many of the villagers but also of the students and volunteers. Some of the students have changed their life-long professional goals as a result. Many medical personnel have told us repeatedly that our radios have saved many lives. The long term vision is to have a whole university partner with networks of villages to address the many community needs and the learning needs of students in many disciplines in a sustainable way.
\end{abstract}

There is a danger in the apparent popularity in students participating in service projects in developing countries involving "one-shot" designs and installations in which there is no sustained involvement for training, maintenance, and replacement. The importance of continual training of local personnel, of periodic maintenance and adjustment, of learning and redesigning from operating experience cannot be overemphasized.

Index terms - International, sustainable, multidisciplinary, continuity 


\section{INTRODUCTION}

Basic human needs in the world abound: More than 1.2 billion people in the world do not have access to clean water (World Health Organization (WHO) 2008.) According to the United Nations, 1.8 million people die because of diarrhea per year and 88\% of these cases are related to the ingestion of contaminated water, lack of sanitation and bad hygiene practice (United Nations Development Program (UNDP) 2006.) One-fourth of the world is without grid electricity (International Energy Agency (IEA) 2006), about one-half is living on less than \$2 a day (World Bank 2004; Central Intelligence Agency 2008,) and one-sixth living on less than $\$ 1$ a day and barely surviving (Sachs 2005; World Bank 2004.) The bottom $40 \%$ of the world's population has $0.6 \%$ of total global household wealth, while the top $1 \%$ has $40 \%$ of the world's household wealth, with official exchange rates as a basis of comparison (Davies, et al. 2007.)

From an engineering student's perspective, such statistics can generate concern and a desire to help the world's poor, but they can also be overwhelming. However, students can work together to make a real difference among the poor if they join a program with continuity in one area of one country. Different students can carry out service-learning projects year after year for the same network of villages and can partner with non-engineering students and students from other academic institutions. Such is the evolving model of Village Empowerment: a commitment to a sustainable partnership among students, faculty, and professional volunteers from multiple disciplines and institutions and Quechua villagers in one region in Peru. That is not to say that the program cannot expand to other regions. In fact, the program is extending to American Indian reservations and possibly to other areas of the world but not at the expense of the original commitment to Quechua villagers. What follows is a brief history of the program, descriptions of student projects, courses into which these service-learning projects have been integrated, initial assessment of the success of the projects, and lessons learned.

\subsection{Program Background}

The program had its beginning in the summer of 1997 when a group of undergraduates wanted to do international service work and asked the then university chaplain Fr. Paul Soper. He and the students visited mountain communities in the Peruvian Andes, in the area of the city of Huarmey. Huarmey is a coastal city, on the Pan-American Highway, about $300 \mathrm{~km}$ north of Lima. Two rivers, the Rio Huarmey and the Rio Culebras converge on Huarmey. Along these two river valleys are located about fifty villages. Though Huarmey has electricity, telephones, and a hospital staffed by several doctors and nurses, the mountain communities are generally without electricity or communication. The larger villages have clinics staffed by a trained medical technician and have schools, some up to grade 12, typically without even books and paper. Some of the villages rely on water from rivers that had to be hand-carried to houses and clinics. The original group of students approached the engineering school for collaboration. In the summer of 1998, engineering students from the solar engineering graduate program and other undergraduate programs started going down twice a year. A few years later as a result of working with Rotary International, we ventured an hour north of Huarmey to the town of Casma, which has a similar hospital and village network. We now have more villages served in the 
Casma network than those of Huarmey. The region around Quillo in the Casma network is reportedly one of the two poorest areas in all of Peru.

In the eleven years of the project (which we now call Village Empowerment), we have installed over 80 systems in 44 villages and towns in two different hospital networks (Huarmey and Casma). More than 119 students and volunteers and 4 faculty, from University of Massachusetts Lowell (UML) as well as other universities, have participated in this project and made 23 trips to Peru. All of these systems were designed and installed by undergraduate and graduate students and local people, assisted by faculty and experienced volunteers.

The original goals of the program were:

- To advance international understanding and cooperation through collaborative development of innovative solutions that support mutual cultural and technical learning;

- $\quad$ To explore the use of renewable energy in the Andes in ways that bring local Peruvian residents and UML students together to work in partnership;

- $\quad$ To optimize educational experiences of students involved through the integration of service and learning, what is termed service-learning (S-L);

- $\quad$ To promote local economic development within Peru.

The program has evolved to develop not just renewable energy systems but systems that in general meet the health care, education, communication, energy, water, food production, and housing needs of villages in a sustainable way. It has also evolved to include not just UML students but also students from other universities, along with a few volunteers, from many different fields. The long term vision is to have a whole university partner with this network of villages to address the many community needs and the learning needs of students in many disciplines.

Many of these systems formed service-learning projects, in which real community needs are met while academic course objectives are covered in a course (J. J. Duffy, Service-Learning in a Variety of Engineering Courses 2000.) An outgrowth of the Village Empowerment program is the SLICE program (Service-Learning Integrated throughout a College of Engineering), which has as its aim the integration of service-learning projects into key required courses so that undergraduate students in the college of engineering have at least one course every semester with S-L (Duffy, et al. 2007.) We seek to not add any additional courses nor add time in existing courses for the students, but to replace existing paper projects with "real" hands-on projects that are useful to those in need. Another goal is to attract underrepresented groups into engineering. The Village Empowerment program is the source of S-L projects for 25 different courses at UML and -at other universities.

Many of these systems utilize renewable energy to provide lights, transceiver radio communication, laptop computers, educational experiments/lessons, water supply, drinking water purification, and various medical needs: vaccine refrigeration, nebulizers, and sterilizers. These systems are powered by photovoltaic (PV) modules, solar thermal collectors, and micro hydro generators, to provide for continued sustainability (in energy supply, economic costs, and environmental impact.) More and more of the radio systems are utilizing the electrical grid as power lines spread to more villages in the region. 
We have chosen to focus on infrastructure development for a variety of community end uses in a relatively small network of villages in order to help ensure the sustainability of these systems. We return to existing systems to keep maintaining and improving them and, rather than spread ourselves too thin geographically, we expand the types of infrastructure needs met in the same network (health care, education, communication, energy, water, food production, housing.) The sustainability of these infrastructure systems is a key goal of our program in keeping with vision of a balance between advance of technology and preservation of the natural environment and culture of the Quechua (Inca) people.

Although the VE program is similar to Engineers Without Borders (Engineers Without Borders (EWB) 2008) and Engineers for a Sustainable World (Engineers for a Sustainable World 2008,) it differs in several key ways: It is older; it is focused on sustained commitment to one region; it is tightly linked to service-learning in a variety of courses; it is interdisciplinary with students and professional volunteers from other disciplines besides engineering involved to address a widening variety of villages needs: health care, education, communication, energy, water, food production, and housing.

\section{OVERVIEW OF SYSTEMS}

The system descriptions and results are presented by general category, since we have expanded into a number of types of systems. Examples are illustrated in Figures 1 to 4 below.

\subsection{Communication}

In these villages there are either no telephones or perhaps one pay phone for up to 500 people. We now have two radio transceiver communication networks encompassing a total of 35 clinics in small villages and two hospitals in coastal towns. We use the ham radio band (2 m wavelength) and generally $5 \mathrm{~W}$ handheld units (for low standby loss) with $35 \mathrm{~W}$ amplifiers. Fifty W photovoltaic modules are used with charge controllers with low voltage disconnect. Flooded lead acid batteries made in Peru have a storage capacity of 120 to 140 Ah; they are fairly heavy duty but not specifically deep discharge. We tend to over design the storage to prevent deep discharging the batteries. Some batteries have been in service for seven years. The systems have been fairly reliable. Mechanical parts on the radios, like microphone on-off switches and posts for $12 \mathrm{~V}$ power supply plug, wear out from a significant amount of use. The feedback we get from the villagers and medical staff is that these radios have improved health care delivery and in fact have saved many lives.

\subsection{Water Supply and Purification}

To give an idea of the impact that some of the systems have had, consider the situation in the towns of Quian and Huayash. Not only do the people in these villages have no electricity but also they had to hand carry water in buckets to their houses, which in some cases are a half mile 
away. Students designed and installed two different solar-powered water supply and drinking water purification systems using two different technical approaches. The one in Quian uses a spring and gravity to provide water and a UV light to purify the drinking water (Hart, et al. 2003); the other pumps water from a river to an elevated tank and uses sand filters to purify the drinking water. In each case, individual families on their own have connected their houses to our common water supply points. A 74-year-old man insisted on helping paint the water tanks in Huayash in January 2004 since he said he has water in his house for the first time in his life!

In addition, in the town of Quillapampa we installed a PV-powered pump to draw water from a well in addition to piping and a storage tank on a hill above the town. We encouraged the villagers to use the SODIS method of water purification (Swiss Federal Institute for Environmental Science and Technology (EAWAG); Department of Water and Sanitation in Developing Countries (SANDEC) 1998,) in which ordinary recycled soda bottles filled with relatively low-turbidity water can be disinfected in sunlight in about a half day. We are working on coating the bottles with $\mathrm{TiO}_{2}$ photo catalyst (with locally available materials) to speed up the disinfection rate and to remove other contaminants and adding a dye indicator to the solution to let the users know when the water is ready (Heredia and Duffy 2007.)

Solar water pumping systems have also been designed and installed in Muchipampa, Utcu, Yanacaca, and Laguna at the request of the villagers. We have also designed and built two solar pasteurizers with flat plate collectors for village medical clinics. Getting the folks to use the disinfection systems in general is a struggle. From our own observations and those of the medical personnel, the people are not convinced they really need disinfected water. Based on our testing, none of the water in any of the villages is suitable to drink without treatment. Of the four water disinfection systems we have tried (solar pasteurization, UV light, sand filter, SODIS bottles,) there is no clear "winner" although the prospects of the photo catalyst water bottles are very encouraging.

\subsection{Lighting and Personal Computers}

We have installed over 20 lighting systems in clinics, schools, churches, and town halls, with roof top PV modules, and about 25 portable lanterns in clinics, recharged from the PV panels. We have found the Sollatek Lumina compact fluorescent lights the most reliable, although expensive. More recently we are using CFL dc bulbs with Edison bases, which appear to be just as reliable and easier to replace. The sealed lead batteries in the lanterns seem to last about two to three years. We are slowly replacing the lanterns with LED headlamps and rechargeable batteries, which are cheaper and more portable and use less energy. The headlamps are better for task lighting rather than area lighting (Tavaranan and Duffy 2005.)

We also have about 20 laptop computers in clinics and 10 in schools along with donated software with lessons, most powered from PV modules and battery storage systems. In all the schools, the teachers are asking for more solar panels and more laptops so the students can use the PCs longer. The schools otherwise have essentially no books and hardly any paper. The effect of the One Laptop Per Child project may be beneficial eventually. 


\subsection{Vaccine Refrigeration and Other Medical Equipment}

The designs and prototypes of vaccine refrigerators, both stationary and portable, have been undergoing continuous development and improvement over the whole period of the project. We have been trying to utilize thermionic modules and phase-change material for lower cost (e.g. Trelles and Duffy 2003.) But it is hard to improve on the efficiency of the vapor compression refrigeration approach for in-clinic use, particularly since recently two small fridges have been become available commercially, which we find through continuous field monitoring are twice as efficient as the thermionic module fridges. Their reliability, however, leaves something to be desired. We continue work on a portable solar-powered vaccine refrigerator (Jiajitsawat and and Duffy 2006.)

We have had data loggers at three different clinics to provide feedback on how well the solar systems are doing and to provide weather data to help design new systems for the area. The average annual horizontal global irradiation is measured by an SPLite pyranometer from Kipp and Zonen every second and averaged and stored every hour. The average daily irradiation measurements are estimated so far as: Malvas $6.1 \mathrm{kWh} / \mathrm{m} 2 /$ day (elev. $3100 \mathrm{~m}, 9.9^{\circ} \mathrm{S}, 77.7^{\circ} \mathrm{W}$ ); Raypa $5.0 \mathrm{kWh} / \mathrm{m}^{2} /$ day (elev. $1400 \mathrm{~m}, 9.6^{\circ} \mathrm{S}, 77.9^{\circ} \mathrm{W}$ ); and Cochapeti $4.6 \mathrm{kWh} / \mathrm{m}^{2} /$ day (elev. $3400 \mathrm{~m}, 9.98^{\circ} \mathrm{S}, 77.6^{\circ} \mathrm{W}$.)

A solar autoclave was developed by another group of undergraduates (Figure 4.) It utilizes a locally made parabolic concentrator and a modified pressure cooker. On a sunny day, only one set up needs to be performed on the parabolic dish to direct it towards the sun, and the steam is generated at the proper pressure and temperature for the required half hour to sterilize medical instruments.

Other medical devices students have developed include an oxygen mask utilizing a recycled soda bottle and plastic bag that uses $80 \%$ less oxygen than the commercial masks available in the US. A prosthetic leg for a young girl was developed by undergraduates, and another team produced prosthesis for a young man and also developed a more generic design and model utilizing locally available materials and manufacturing processes.

We have had nursing students as well as physical therapy (PT) Professor Deirdra Murphy and a graduate student who, as part of courses, have made assessments of health needs in many of the villages and brought down appropriate equipment and trained local folks in its use. Some PT students worked with engineering seniors to design and build special playground rides for children with disabilities.

\subsection{Micro hydro}

Students have designed four micro hydro systems and installed three of them. In two cases there was less water available than we had estimated, and we are in the process of moving the systems to other villages. The San Miguel system was working quite well with a Harris turbine-generator at $48 \mathrm{dc}$ and an inverter with an output of $230 \mathrm{~V}$ ac $60 \mathrm{~Hz}$ (the standard in Peru.) Twenty-five $20 \mathrm{~W}$ fluorescent street lights were lit by the micro hydro every night from about 6 to 9 pm for 
several years. The town has since received power from the electric company, and the town and $\mathrm{VE}$ are in the process of moving the hydro system to a nearby village that likely will never have grid electricity.

\subsection{Biogas}

In the last couple of years students have adapted designs of biogas digesters to generate methane gas for cooking from farm manure (Solis 2006.) Two systems have been installed as prototypes. Wood stoves and fireplaces are used for cooking otherwise. Smoke is harmful to the occupants of the houses.

We are also starting to work with farmers to reduce the use of chemical pesticides and herbicides and protect workers from exposure.

\subsection{Health Care Programs}

We have not only hardware systems developed by students but also recently educational and clinical activities. On the June 2008 trip professor of Physical Therapy Deirdra Murphy and professor of Health Education Nicole Champagne traveled with two students each to work with folks with disabilities, hold workshops for expectant mothers, instruct children in sanitation, and assess community health status.

\subsection{Microenterprise: Aquaculture, Solar Lanterns/Headlamps, Drip Irrigation, Water Purification Bottles}

All the systems discussed so far have been for the communities, not individuals. It appears, however, that to make development more sustainable in the villages small businesses must also be started. We have been assisting in business development of aquaculture systems for trout and crayfish in three villages to also improve the diet. Trout are difficult to raise, and the concrete pools expensive to build high up in the mountains. Crayfish, on the other hand, are relatively hardy and require only earth-lined ponds. Two crayfish farms were built and tested.

A second business venture involves selling or renting solar lanterns for room lighting and headlamps for reading or working. Twenty lanterns were built in Lima with as many locally available parts as possible, based on a design by (Tavaranan and Duffy 2005.) A PV charging station was installed in Quian as a test site for rentals as well as one in Fortaleza. A marketing survey indicated a high degree of interest in Quian and other villages in buying or renting the lanterns and LED headlamps with rechargeable batteries, also under development. Kerosene lamps and candles for lighting are expensive, emit harmful gases into homes, and cause fires.

A solar drip irrigation has been designed and installed in the village of Laguna. The installation is allowing double yields of asparagus per year. The relative costs of the solar drip irrigation system are low compared to diesel pumping systems with flooding irrigation. 
Another microenterprise in development involves the manufacturing of photo catalyst-coated plastic bottles for solar water purification with a dye indicator. Research is underway to simplify the manufacturing process and to ensure safety in the steps of making and using this approach (Heredia and Duffy 2007, Dubro and Duffy, Dye Indicator for the Effectiveness of TiO2 Water Purification 2007.) The results to date are very promising for a low cost approach that could be used for water purification and storage in Peru and in many other parts of the world. Two business classes at UML were involved with developing business plans for the solar water bottle microenterprises.

\subsection{Courses}

A unique aspect of the VE program is its tie in with service-learning projects in a large number of different types and levels of courses. The courses and example projects are listed in Table 1 in order to provide ideas for other faculty members and students.

\section{TABLE I}

\section{COURSES WITH S-L PROJECTS FOR THE VE PROGRAM}

\begin{tabular}{|c|c|c|c|c|c|c|c|}
\hline $\mathrm{Yr}$ & Course & $\mathrm{Cr}$ & Course Title & Faculty & Activities & $\begin{array}{c}\text { \# S-L } \\
\text { students }\end{array}$ & \begin{tabular}{|c|} 
\# of \\
students
\end{tabular} \\
\hline So & 16.208 & 3 & Basic EE Lab II & Alan Rux & $\begin{array}{l}\text { LED analysis for headlamp design for } \\
\text { Peru }\end{array}$ & 36 & 36 \\
\hline $\mathrm{Sr}$ & 16.499 & 3 & EE Capstone II & John Duffy & $\begin{array}{l}\text { Transfer of emails and files via } \\
\text { transceiver radio modems and PCs in } \\
\text { Peruvian clinics and Wi-Fi prototype. }\end{array}$ & 3 & 3 \\
\hline $\mathrm{Jr}$ & 45.334 & 3 & $\begin{array}{l}\text { Engineering Ethics } \\
\text { (required for } \\
\text { engineering students) }\end{array}$ & Gene Mellican & $\begin{array}{l}\text { Research the ethical pros and cons of } \\
\text { introducing TV into remote Peruvian } \\
\text { villages. }\end{array}$ & 120 & 120 \\
\hline $\mathrm{Sr}$ & 22.342 & 3 & Convective Processes & Gene Niemi & $\begin{array}{l}\text { Piping design of water supply system } \\
\text { for Yanacaca village, Peru }\end{array}$ & 47 & 47 \\
\hline $\mathrm{Jr}$ & 22.361 & 3 & \begin{tabular}{|c|} 
Mathematical \\
Methods for \\
Mechanical Engineers
\end{tabular} & John McKelliget & $\begin{array}{c}\text { Statistical analysis of health indicators } \\
\text { in Peruvian villages with systems from } \\
\text { VE project ( } 5 \% \text { of grade) }\end{array}$ & 65 & 65 \\
\hline $\mathrm{Jr}$ & 22.381 & 3 & Fluids & Majid Charmchi & $\begin{array}{c}\text { Design irrigation system to supply } \\
\text { water for asparagus in the rural } \\
\text { community of Laguna, Peru. }\end{array}$ & 8 & 40 \\
\hline $\mathrm{Sr}$ & 22.425 & 3 & $\begin{array}{l}\text { Design of Machine } \\
\text { Elements }\end{array}$ & Chris Niezrecki & $\begin{array}{l}\text { Water tower designs (2) and } \\
\text { motorcycle ambulance connection. }\end{array}$ & 19 & 49 \\
\hline $\mathrm{Sr}$ & 22.423 & 3 & ME Capstone Design & John Duffy & $\begin{array}{l}\text { Prosthetic limbs; sand filter water } \\
\text { purification system; micro hydro } \\
\text { generating plants; low-cost oxygen } \\
\text { masks; hand-powered swings for } \\
\text { disabled children-and install all in } \\
\text { Peruvian villages. (100\% of grade) }\end{array}$ & 30 & 30 \\
\hline So & 26.215 & 1 & Plastics Process Lab I & Carol Barry & $\begin{array}{l}\text { Plasticizer leaching from PVC testing } \\
\text { for Peru water systems }\end{array}$ & 21 & 21 \\
\hline
\end{tabular}




\begin{tabular}{|c|c|c|c|c|c|c|c|}
\hline Gr & 22.504 & 3 & $\begin{array}{l}\text { Energy Engineering } \\
\text { Workshop }\end{array}$ & John Duffy & $\begin{array}{c}\text { Solar water pumping system design and } \\
\text { installation for Laguna, Peru }\end{array}$ & 2 & 2 \\
\hline Yr & Course & $\mathrm{Cr}$ & Course Title & Faculty & Activities & $\begin{array}{l}\text { \# S-L } \\
\text { students }\end{array}$ & $\begin{array}{c}\text { \# of } \\
\text { students }\end{array}$ \\
\hline $\begin{array}{l}\mathrm{Gr} \\
\mathrm{Sr}\end{array}$ & 22.521 & 3 & Solar Fundamentals & John Duffy & $\begin{array}{l}\text { Estimate solar irradiation and optimal } \\
\text { tilt for a solar collector and install in } \\
\text { Yanacaca in Peru; design a solar hot } \\
\text { water batch collector for a village } \\
\text { biogas system; design and build for } \\
\text { Yanacaca a solar herb crop dryer. }\end{array}$ & 12 & 12 \\
\hline $\begin{array}{l}\mathrm{Gr} \\
\mathrm{Sr}\end{array}$ & 22.527 & 3 & $\begin{array}{l}\text { Solar Systems } \\
\text { Engineering }\end{array}$ & John Duffy & $\begin{array}{l}\text { Carbon displacement credit assessment } \\
\text { of PV systems in Peruvian villages; } \\
\text { solar water pumping system data } \\
\text { acquisition design and installation for } \\
\text { Huayash, Peru }\end{array}$ & 8 & 8 \\
\hline So & $\begin{array}{l}26.211 \\
22.211\end{array}$ & 3 & Mechanics (Statics) & Amad Tayebi & $\begin{array}{l}\text { Extra credit: tower design for water } \\
\text { tank for village school }\end{array}$ & 3 & 60 \\
\hline So & 26.218 & 2 & Intro. to Design & $\begin{array}{l}\text { Steve Orroth, } \\
\text { Nick Schott }\end{array}$ & $\begin{array}{l}\text { Design and manufacture of } \\
\text { rechargeable headlamp casings for } \\
\text { Peru; water prefilters }\end{array}$ & 23 & 23 \\
\hline $\mathrm{Sr}$ & 26.418 & 3 & Plastics Design & $\begin{array}{l}\text { "Francis" Fang } \\
\text { Lai }\end{array}$ & Lanterns for Peru & 8 & 17 \\
\hline $\mathrm{Sr}$ & 25.401 & 3 & $\begin{array}{c}\text { Interdisciplinary } \\
\text { Engineering Capstone } \\
\text { Design }\end{array}$ & John Duffy & $\begin{array}{l}\text { Sand filtration water purification; } \\
\text { biogas system for Peruvian farmers }\end{array}$ & 4 & 4 \\
\hline $\mathrm{Sr}$ & 14.431 & 3 & $\begin{array}{l}\text { Foundation and Soil } \\
\text { Engineering }\end{array}$ & Sam Paikowsky & $\begin{array}{l}\text { Design multiple bridge types for the } \\
\text { village of Yanacaca, Peru }\end{array}$ & 24 & 24 \\
\hline Gr & & 1 & $\begin{array}{l}\text { PT Service-Learning } \\
\text { Practicum }\end{array}$ & Deirdra Murphy & $\begin{array}{c}\text { Select physical therapy equipment and } \\
\text { instructional material and deliver to } \\
\text { Huarmey clinic for disabled; assess PT } \\
\text { needs }\end{array}$ & 2 & 20 \\
\hline $\mathrm{Jr}$ & & 3 & $\begin{array}{l}\text { Service-Learning in } \\
\text { Community Health } \\
\text { Education }\end{array}$ & $\begin{array}{l}\text { Nicole } \\
\text { Champagne }\end{array}$ & $\begin{array}{c}\text { Develop community health assessment } \\
\text { instruments and programs for Peruvian } \\
\text { villages }\end{array}$ & 2 & 2 \\
\hline Sr & & 3 & $\begin{array}{l}\text { Directed Studies } \\
\text { Video History }\end{array}$ & Chad Montrie & $\begin{array}{c}\text { Shoot, produce, edit videos on Village } \\
\text { Empowerment project }\end{array}$ & 1 & 1 \\
\hline $\mathrm{Sr}$ & & 3 & Community Nursing & $\begin{array}{l}\text { Stephanie } \\
\text { Chalupka }\end{array}$ & $\begin{array}{l}\text { Assemble medical supplies and } \\
\text { equipment and deliver to villages in } \\
\text { Peru; assess health needs }\end{array}$ & 2 & 100 \\
\hline $\mathrm{Sr}$ & & 3 & $\begin{array}{l}\text { Writing for the } \\
\text { Community }\end{array}$ & Diana Archibald & $\begin{array}{l}\text { Interview past participants in Village } \\
\text { Empowerment project. }\end{array}$ & 12 & 12 \\
\hline so & 42.227 & 3 & $\begin{array}{l}\text { Essay Writing for } \\
\text { English Majors }\end{array}$ & Diana Archibald & $\begin{array}{l}\text { Write instructional documents, web } \\
\text { content, participant handbook for } \\
\text { Village Empowerment project }\end{array}$ & 24 & 24 \\
\hline Gr & & 3 & $\begin{array}{c}\text { International } \\
\text { Technical } \\
\text { Communications } \\
\text { (Metro State) } \\
\end{array}$ & Helen Carroll & $\begin{array}{l}\text { Develop and test instruction manuals } \\
\text { for } 4 \text { radio types and public health } \\
\text { promotional materials for Peruvian } \\
\text { villages }\end{array}$ & 12 & 12 \\
\hline
\end{tabular}




\begin{tabular}{|c|c|c|c|c|c|c|}
\hline Un & 3 & IIPRO (IIT) & Dan Ferguson & $\begin{array}{c}\text { Design, test low-cost solar cookers, } \\
\text { coolers for Peruvian villages. }\end{array}$ & 6 & 12 \\
\hline
\end{tabular}

\section{IMPACTS}

The Village Empowerment program has transformed the lives not only of many of the villagers but also of the students and volunteers.

\subsection{Participants}

One hundred nineteen students from UML and other universities, faculty, and volunteers have gone to Peru with the program since 1998. Five students went on the first trip in the summer of 1997. Hundreds more have participated in designing and analyzing systems for the program through the many courses listed in Table 1 above. Thirty of the participants have traveled to Peru more than once; the coordinator 20 times and one volunteer leader (Janice Kurkoski) 12 times. Twenty-five students from a dozen other universities have gone down with the "Peru Crew" as it is often called. It is interesting to note that females have chosen to participate in disproportionate numbers: $36 \%$ of the 71 engineering students were female, and for UML 11 of 32 undergraduates (34\%) and 10 of 28 graduate (36\%) students. The UML engineering school female undergraduate enrollment was 10.5\% in Fall 2007 (Office of Institutional Research 2008.) So the participation in the VE program by female undergraduates at UML was more than three times the underlying population. Hispanics represent $28 \%$ of the engineering students participating in the VE program, not too unsurprisingly. Since one of the goals of the SLICE program and the VE program is to increase enrollment/participation by underrepresented groups, it seems the VE program is doing its share to attract female and Hispanic students.

Some of the students have changed their life-long professional goals as a result. At the very least, they have some idea of what it is like to be very poor and to understand, and perhaps eventually alter, world events. One said he can't take a drink of water even now without thinking of the villagers. The project has helped university students learn professional skills of sustainable technology development applied to human and environmental needs while becoming citizens of the world.

Many students joining the VE program reported an increase in their level of confidence and enhanced capacities to improvise and problem-solve. All the participants have been asked to comment on what difference they thought they made on the communities, what difference the communities made on them (personally and professionally), and suggestions for improvements in the program and/or the systems installed. One female student remarked, "we had to problemsolve, for example, find a way to get solar panels onto roofs." Students also commented on the enormous sense of accomplishment, seeing their designs implemented, the potential to make an impact, a new passion for their vocation, and a chance to see the lives that can be changed by their work. As related by one female student, "When you know that your work will impact someone's life, you know you need to get it right, and it makes you driven to succeed. I think 
that all too often, students are more focused on just getting the work done, rather than on the impact their work may have in the future." Another female student commented that, "the obstacles were learning experiences. I learned much more from solving community problems than from pushing paper."

Some stated that the project helped them to decide on careers involving this kind of work. "Moreover I found out for me that this is the kind of work [engineering projects for the poor in developing countries] that I'd like to do after I have finished my studies." Another graduate worked on solar systems in remote refugee camps in Thailand for three years. Another is working on renewable energy systems for Indian reservations in the US and Canada.

Many more student comments as well as narratives on almost each of the 21 trips since 1988 are given under "journal” at the web site: http://energy.caeds.eng.uml.edu/peru-07/index.shtm.

\subsection{Villagers}

We make a point of helping local folks with systems that they request and that are environmentally, economically, politically, and culturally appropriate and sustainable. They in turn help us learn to be better professionals and better citizens.

Assessment of the impact of the VE program on the villages is straightforward in some ways. For example, providing running water and water purification to whole villages, transceiver radio communication, lighting in medical clinics and town halls, vaccine refrigeration, biogas for cooking - these are all obviously positive. Microenterprises with loans for entrepreneurs are expected to help sustainable development in the villages.

Medical personnel in the clinics have told us repeatedly that the radios have saved many lives. In one clinic, the head nurse of the region served told us there were seven deaths in childbirth in the previous six months to our installing a solar radio system. We returned six months after the radio had been installed to find there were no deaths! The lights, vaccine refrigerators, laptop computers, and water supply systems have helped increase productivity and have helped deliver better health care and education.

On the trip in January 2008, UML professor of Literature Diana Archibald and professor of History Chad Montrie went along with video cameras to create a documentary on the program, to include student villager interviews, for assessment and dissemination purposes. Students are helping in the process. Initial results are available at http://energy.caeds.eng.uml.edu/peru07/index.shtm.

The program has received some awards recently: a Jimmy and Rosalynn Carter Partnership Foundation endorsement as a finalist in the Massachusetts Campus Compact for a Carter award in April 2007; a Boston Celtics "Heroes Among Us" award in March 2007; and a University of Massachusetts President’s Award for Service in December 2006. 
Assessment of the impact of the program on students and community members is a continual process. For example, three students (David Curtin, Bonnie Tacheron, and Robert Williams) spent the whole summer of 2008 in part to evaluate the program. Results are being analyzed.

\section{SUSTAINABILITY}

There are several aspects of sustainability of renewable energy systems in remote areas: user training, investment by the community, maintenance, reliability, cost-effectiveness. We address these issues in the following ways. We have held workshops for the users of our systems (medical personnel, teachers, town leaders.) We provide manuals on the principles of operation, use, and maintenance of the systems in Spanish. Unfortunately, there is a high turnover typically of medical personnel in the villages because the government wants to save money by not hiring "permanent” employees. We have to retrain constantly.

In developing manuals, we have partnered with the Technical Communication graduate program at Metro State University in Minneapolis for the use and maintenance of the devices and systems. Professor Helen Carroll has incorporated S-L projects into her courses in international technical communications for these manuals but also posters and coloring books for public health promotion in the villages. She and a fellow professor sent several of their students to travel to Peru with the VE program to test and refine the media they developed. The manuals have made a big difference in the ease of use and lowered repair rates of the radios, in particular.

On another aspect of sustainability, we have had now six graduate students in our solar engineering program from Peru. Each of these students has been very active in participating in the VE program, providing political, cultural, economic background to the "gringos" participants. The long-range hope is to have at least one or two of them return to teach in a university in Peru and partner with us and their students to continue the work in the villages. Many people who live in Lima have just as much chance of visiting the remote villages as Americans do. In about four of "our" villages, we were told that we are the first US people to ever have set foot in those villages.

We try to get the villagers to make simple repairs in case of trouble. We also have a radioemail network of sorts over which we can feedback suggestions on how to troubleshoot and fix problems. Sometimes repairs have to wait until we visit on the next trip. But we do keep coming back. At first the villagers could not believe that we kept our word about returning. Apparently not many people do keep their word to them. Spare parts are kept in the parish house in Huarmey. We have left some spare parts at the two base hospitals with notes for replacements, but security of the parts is a big concern.

The people in the villages invest in the systems through the labor they provide in installing the systems, i.e., "sweat equity." Our policy is not to do things for the people but with them.

We try to utilize reliable components in the systems. Batteries in general have lasted up to seven years, but a few have failed prematurely. Radio parts just wear out from heavy use. Three 
PV modules have failed, one from water leaks, and two from chemical failure of the coating on flexible polycrystalline modules. One battery charge controller failed. We had one PV array of seven modules fail because of corrosion of wire connections on the roof. We now use antioxidant grease on all our connections.

Finally, there is a danger in the apparent popularity in students participating in service projects in developing countries involving “one-shot” designs and installations in which there is no sustained involvement for training, maintenance, and replacement. Such systems typically fail sooner or later and can result in local people concluding that "solar does not work." Such installations ultimately do no good for the local people or for the long-term prospects of solar systems being accepted. The importance of continual training of local personnel, of periodic maintenance and adjustment, of learning and redesigning from operating experience cannot be overemphasized. Initial design taking into account sustainable energy, economics, and cultural impact is not enough.

\section{ConClusions}

In summary, since 1998, as part of the Village Empowerment Program, 119 students/volunteers from University of Massachusetts Lowell (UML) and several other universities in engineering and other fields have traveled twice a year to the same network of villages in Peru. UML students in service-learning projects in more than 25 different courses have designed and helped install over 80 systems, most running on renewable energy, in 44 villages and towns in the Andes Mountains of Peru for medical clinics, schools, and town halls.

What are the lessons learned from this program? Working for one semester on a servicelearning project in a course to design a system to meet real needs of villagers and then traveling to Peru for two weeks to help install and test the system has had a profound, lasting effect on at least some students. But to have a lasting positive effect on the villagers continuity and sustainability of the program are essential beyond a one-time visit.

We close with what a student who had designed and helped build a sand filter system in the village of Huayash told a reporter from the Lowell Sun, "This is the best thing I have ever done." We hope to be able to continue providing students and villagers with the opportunities to partner to do, and be, their best.

\section{ACKNOWLEDGEMENTS}

Thanks to 119 students, faculty, and volunteers who have traveled to the villages in Peru (see http://energy. caeds.eng.uml.edu/Peru-07/participants.shtm for the list) as well as the students who designed systems but did not travel and to the many local folks in the villages with whom we worked to install and maintain the systems. The support of Rotary International; NCIIA; New England BioLabs Foundation; St. Mary’s Parish, Winchester, MA; former UML Chancellor William Hogan; ASE Americas, Evergreen Solar, and AstroPower for photovoltaic module donations; and many individual donors is gratefully acknowledged as well as partial support 
from the National Science Foundation for service-learning throughout the college (Grants EEC0431925 and EEC-0530632.) Any opinions, findings, and conclusions or recommendations expressed in this material are those of the author and do not necessarily reflect the views of the National Science Foundation.
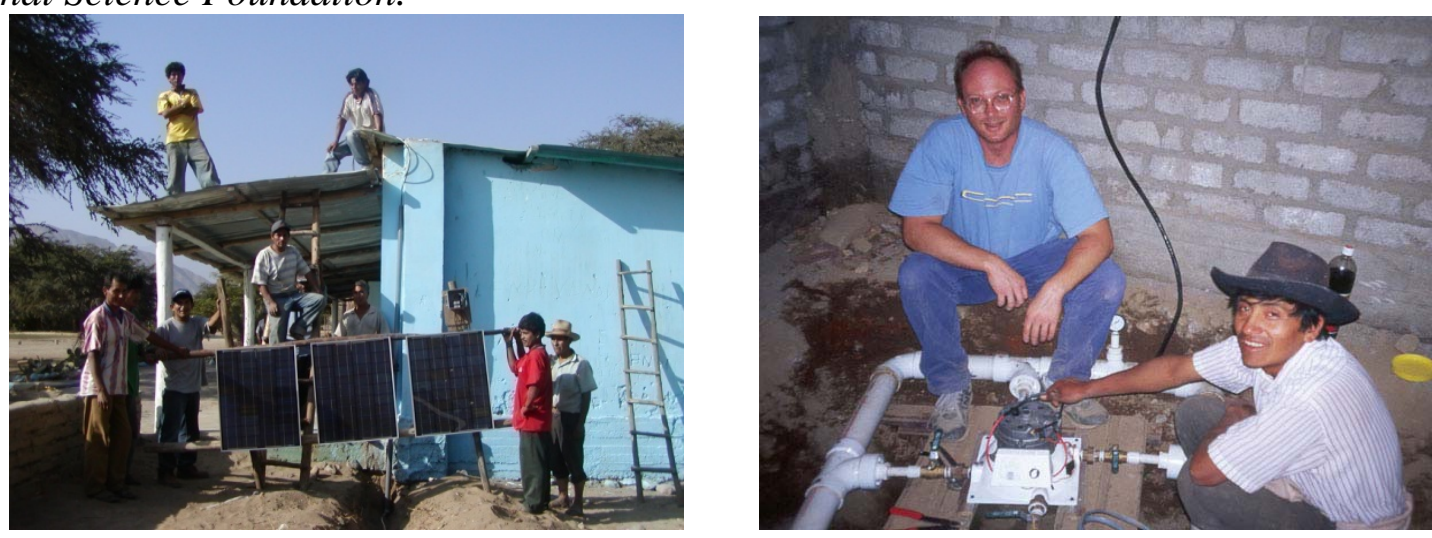

FIGURE 1

PV PANELS GOING UP IN QUILLAPAMPA AND MICRO HYDRO INSTALLATION.
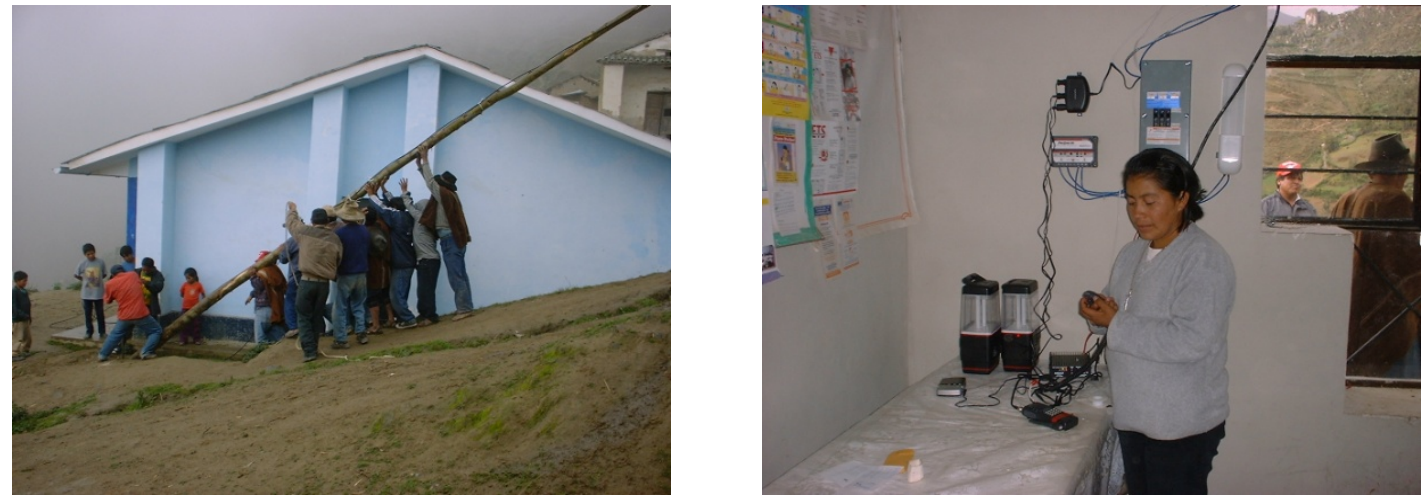

FIGURE 2

RAISING AN ANTENNA IN CHIPRE AND MEDICAL TECHNICIAN WITH TRANSCEIVER RADIO, LIGHTS, LANTERNS. 


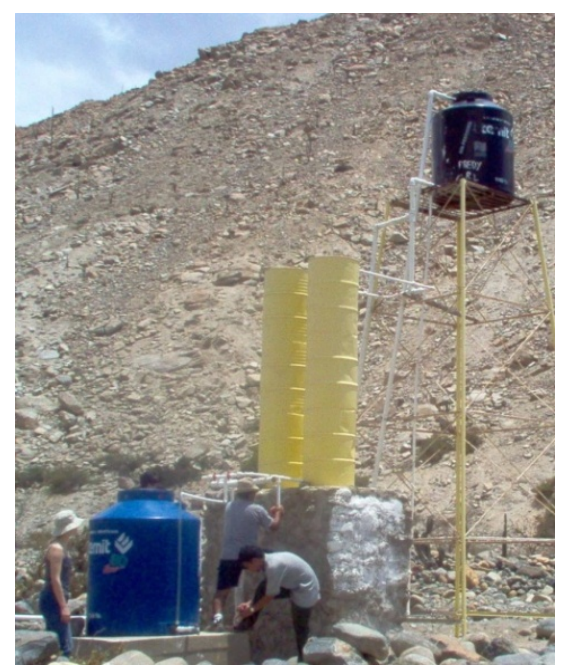

FIGURE 3

HUAYASH SOLAR-PUMPED WATER SYSTEM SAND FILTERS.

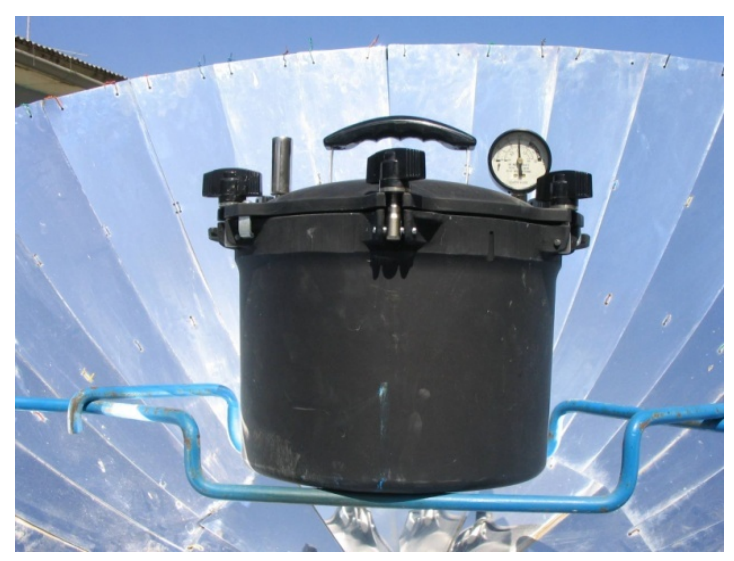

FIGURE 4

SOLAR AUTOCLAVE IN HUAMBA. 


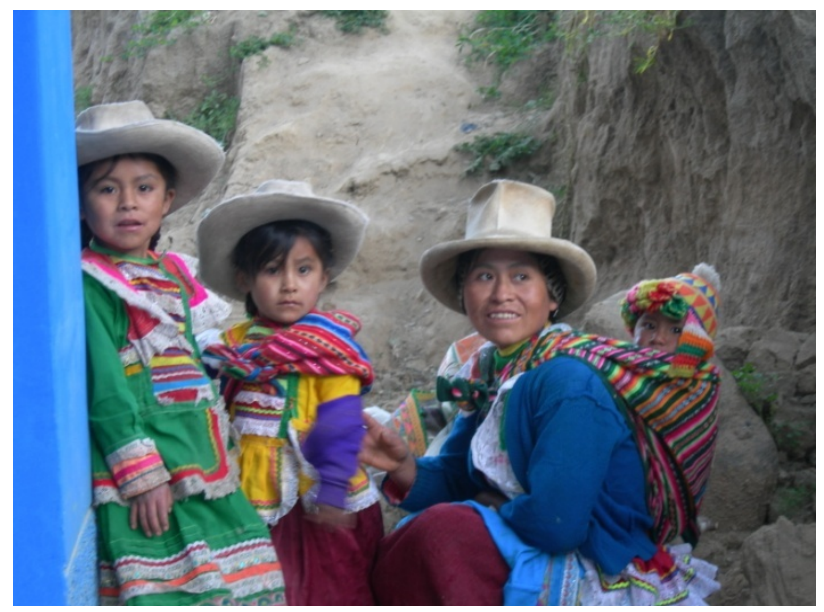

\section{FIGURE 5 \\ QUECHUA VILLAGERS.}

\section{REFERENCES}

Central Intelligence Agency. "World Fact Book." 2008. https://www.cia.gov/library/publications/the-worldfactbook/index.html (accessed September 14, 2008).

Davies, J. B., S. Sandström, A. Shorrocks, and E. N. Wolff. Estimating the Level and Distribution of Global Household Wealth. UNU-WIDER Research Paper No. 2007/77. United Nations University, 2007.

Dubro, Peter. "Dye Indicator for the Effectiveness of TiO2 Water Purification." MS Thesis, Energy Engineering. Lowell, MA: University of Massachusetts Lowell, 2007.

Dubro, Peter, and J. J. Duffy. "Dye Indicator for the Effectiveness of TiO2 Water Purification." Proceedings Annual Meeting American Solar Energy Society. Boulder, CO: American Solar Energy Society, 2007. CD.

Duffy, J.J., et al. "Service-Learning Integrated into Existing Core Courses throughout a College of Engineering." Proceedings American Society of Engineering Education Annual Conference. Washington, DC: American Society of Engineering Education, 2007. CD.

Duffy, John J. "Service-Learning in a Variety of Engineering Courses." In Design That Matters: Service-Learning in Engineering, by Edmund Tsang, 75 - 98. Washington, DC: American Association of Higher Education, 2000.

—. "Peruvian Villages Go Solar." Solar Today, ASES magazine, Nov. 1999: 30 - 31.

Engineers for a Sustainable World. Engineers for a Sustainable World (ESW). 2008. http://www.esustainableworld.org/about/mission.asp (accessed January 18, 2008).

Engineers Without Borders (EWB). Engineers Without Borders (EWB). 2008. http://www.ewb-usa.org/about.php (accessed January 18, 2008).

Hart, J., M. MacDonald, S. Montminy, and J. J. Duffy. "Drinking Water Purification System for Remote Villages Utilizing Ultraviolet Radiation and Photovoltaics." Proceedings Annual National Solar Conference. Boulder, CO: American Solar Energy Society, 2003. CD.

Heredia, M., and J. Duffy. "Photocatalytic Destruction of Water Pollutants Using a TiO2 Film in PET Bottles." ASES Annual Conference Proceedings. Boulder, CO: American Solar Energy Society, 2007. CD.

Heredia, Manuel. "Photocatalytic Destruction of Water Pollutants Using a TiO2 Film in PET Bottles." MS thesis, Energy Engineering Program. Lowell, MA: University of Massachusetts Lowell, 2006.

International Energy Agency (IEA). "World Energy Outloook 2006." World Energy Outlook. 2006. http://www.worldenergyoutlook.org/summaries2006/English.pdf (accessed April 29, 2007).

Jiajitsawat, S., and J. J. and Duffy. "A Portable Direct-PV Thermoelectric Vaccine Refrigerator with Ice Storage through Heat Pipes." Proceedings of the 2006 National Solar Energy Conference. Boulder, CO: American Solar Energy Society, 2006. CD.

Office of Institutional Research. "Factbook." University of Massachusetts Lowell. 2008. http://www.uml.edu/it/ir/FB2008/FB2008.pdf (accessed April 15, 2008).

Sachs, J. The End of Poverty. New York: Penguin Press, 2005. 
Solis, J. "Hybrid Biogas and Solar Collector System for Low Ambient Temperatures." MS thesis, Energy Engineering Program (Solar). Lowell, MA: University of Massachusetts Lowell, 2006.

Sunada, K. T., and K. Hashimoto. Watanabe. "Studies on Photokilling of Bacteria on TiO2 Thin Film." Photochemistry and Photobiology A, 2003: Chemistry 156, 227-233.

Swiss Federal Institute for Environmental Science and Technology (EAWAG); Department of Water and Sanitation in Developing Countries (SANDEC). "SODIS Technical notes (No. 1-17)." SODIS. 1998. http://www.sodis.ch/files/notes.p (accessed April 14, 2007).

Tavaranan, S., and J. J. Duffy. "Solar Lanterns for Remote Areas." World Solar Congress Proceedings. Freiburg, Germany: International Solar Energy Society, 2005. CD.

Trelles, J.P., and J.J. Duffy. "Numerical Simulation of Porous Latent Heat Thermal Energy Storage for Thermoelectric Cooling." Journal of Applied Thermal Engineering, 2003: 23 (13), 1647-1664.

Tsang, E. (Ed.). Design That Matters: Service-Learning in Engineering. Washington, DC: American Association of Higher Education, 2000.

United Nations Development Program (UNDP). "Human Development Report: Beyond Scarcity: Power, Poverty and the Global Water Crisis." UNDP. 2006. http://hdr.undp.org/hdr2006/ (accessed April 14, 2007).

World Bank. "Partnerships in Development: Progress in the Fight Against Poverty." World Bank. 2004. http://web.worldbank.org/WBSITE/EXTERNAL/EXTABOUTUS/0,,contentMDK:20104132 menuPK:250991 pagePK:43912 piPK:44037 theSitePK:29708,00. (accessed April 29, 2007).

World Health Organization (WHO). "Water Supply and Sanitation Collaborative Council, Putting People at the Center." WSSCC.

2008.http://www.wsscc.org/fileadmin/files/pdf/publication/WSSCC_brochure_online_version.pdf (accessed February 28, 2008). 